\title{
Efforts to Improve Kolintang Learning Through the Spiral Approach in SMP Bruderan Purworejo
}

\author{
Irene Priesta Pasca Priawara ${ }^{1, *}$ Hanna Sri Mudjilah $^{2, * *}$
}

\author{
${ }^{1}$ Arts Education Graduate Program, Yogyakarta State University, Depok 55281, Yogyakarta, Indonesia \\ ${ }^{l}$ Department of Music Education, Yogyakarta State University, Depok 55281, Yogyakarta, Indonesia \\ ${ }^{*}$ Corresponding author.Email: irenepriesta@gmail.com \\ ${ }^{* *}$ Corresponding author. Email: hannya@uny.ac.id
}

\begin{abstract}
The purpose of this research is to find out and describe efforts to improve Kolintang learning through the spiral learning approach at SMP Bruderan Purworejo. This study used a spiral learning approach because it was to deal with the difficulties faced by students in learning Kolintang in SMP Bruderan Purworejo. This research was a classroom action research. This study was carried out in SMP Bruderan Purworejo with students of Class VIII B in the 2016-2017 Academic Year as the targets. The results showed that by implementing the spiral learning, students could succeed and achieve increasing grades as seen from the average score in the pre-cycle class of 62.2 , in the first cycle of 72.9 with a passing percentage of $21.4 \%$ in low category, and in the second cycle of 82.1 with a passing percentage of $100 \%$. In the second cycle, it can be seen that the research is declared successful. Thus, it was concluded that the use of the spiral learning approach can improve Kolintang learning in SMP Bruderan Purworejo.
\end{abstract}

Keywords: Kolintang, spiral learning approach

\section{INTRODUCTION}

Kolintang is one of the learning materials in Junior High School SMP Bruderan Purworejo for the first semester (odd semester) of class VIII. In kolintang learning, problems were found in the learning process. Many students find it difficult to understand Kolintang materials, so some of them became less enthusiastic during learning processes. Kolintang is a traditional percussion instrument from Minahasa [1]. It belongs to the pitch instrument category. This instrument is made of wood formed into blades with a sequence of notes from low to high. When played in a small group, five types of Kolintang musical instruments, namely melody, alto, tenor, cello, and bass are played. Each type of Kolintang instrument has different functions and is played according to its role.

Most schools in Purworejo Regency have more than one Kolintang. However, the only school actively teaching how to play Kolintang is SMP Bruderan Purworejo. However, students who succeed in learning Kolintang in the school are those in the excellent class. The difficulty found in the Kolintang learning process at SMP Bruderan Purworejo becomes the background of this study. This study focuses on using the spiral approach to teach Kolintang in the school.

The spiral learning is a learning approach conducted by presenting materials from the easy to the difficult ones. In kolintang learning using the spiral learning approach, the role and type of Kolintang instruments, i.e. melody, alto, tenor, cello, and bass are presented first. In this study, several methods, namely demonstration, imitation, groupwork, assignment, and drilling are used in accordance with the student's ability. The learning method may be adapted to student learning development.

\section{RESEARCH METHOD}

This study employed the Classroom Action Research (CAR) method because the nature of the object of this research was the problem faced in learning. Lewin develops a model in the form of a system consisting of input, transformation, and output [2]. In the input stage, the diagnosis of the problems faced by the research participant was conducted [2]. In this stage, researchers were the ones who truly understood the problems faced by the students as well as the solutions to the problems. The next stage, transformation, was the stage in which a set of actions was designed in accordance with the student's need If this stage was not completed, the researcher could repeat the process in the input stage namely identifying the problems and planning new actions to overcome the problems. Otherwise, if there was a desired behaviour change, the research would be further proceeded by conducting tests to check student's improvement. The result of the test became the source of evaluation to determine whether further corrective actions or improved plans were needed. 


\section{Research Setting and Target}

The study entitled "Efforts to Improve Kolintang Learning through the Spiral Learning Approach in Bruderan Purworejo Junior High School Class VIII B in the 2016-2017 Academic Year was carried out at SMP Bruderan Purworejo, Central Java. It is located at K. H. Wahid Hasyim Street No. 3, Purworejo, Central Java. The research participants were VIII B students in the 20162017 academic year.

\section{Research Collaborator}

According to Kunandar, teachers who play a role as a researcher in his class must coach teachers who observe (collaborator or participant) [3]. In this study, the research collaborator was Bernadetta Hartiningsih, S.Pd. who worked as a teacher of the Art and Culture lesson at SMP Bruderan Purworejo. In this classroom action research, a collaborator task was assisting the researcher in planning the implementation of kolintang learning and observing the kolintang learning process.

\section{Research Procedure}

This research is classroom action research (CAR). According to Lewin, three actions carried out during research are input, transformation (process), and outcome.

\section{Data Collection Technique}

In this study, researchers used several data collection techniques to obtain and collect data related to research. The data were collected through observation, unstructured interviews, and documentation. According to Riduwan, observation is a data collection technique in which the object of the research and activities conducted in classes are closely observed [4]. On the other hand, Sugiyono argues that an interview is a meeting of two people to exchange information and ideas by providing questions and answers, and as a result, a meaning of a topic is constructed [5]. Meanwhile, in this study, documentation was done by taking photos and collecting videos, or song scores relating to Kolintang learning at Bruderan Purworejo Middle School.

\section{Research Instrument}

Arikunto states that a research instrument is a tool made used by a researcher in collecting data using certain methods.

Table 1. Assessment Item

\begin{tabular}{|l|l|c|}
\hline No & \multicolumn{1}{|c|}{ Observed Aspect } & Aspect Score \\
\hline 1. & Rhythmic pattern & 5 \\
\hline 2. & Chord & 5 \\
\hline 3. & Accuracy in tone & 5 \\
\hline 4. & Cohesiveness in groups & 5 \\
\hline 5. & How to hold the kolintang stick & 5 \\
\hline Total & $\mathbf{2 5}$ \\
\hline Maximum Score & $\mathbf{1 0 0}$ \\
\hline
\end{tabular}

\section{Data Analysis Technique}

Data analysis techniques used in this study were quantitative descriptive and qualitative descriptive techniques. The quantitative data analysis is a technique in which the data are in the form of numbers obtained from both measurements and changing qualitative data into the quantitative ones. Meanwhile, the qualitative data analysis is a technique to analyze data in the forms of sentences categorized based on the objects being observed.

\section{RESULT AND DISCUSSION}

This study, Efforts to increase Kolintang Learning through the Spiral Learning Approach in SMP Bruderan class VIII B, in the 2016-2017 Academic Year, is carried out in two cycles. At the end of each cycle, the data taken are in the form of students' test scores. Thus, the results of this study are obtained from the pre-cycle as well as an action carried out in the first and second cycles. In the precycle, information about student's chord knowledge is obtained. The results obtained in the first and second cycles are skills in playing folk songs. Meanwhile, the document obtained is in the form of photographs and videos describing the details of activities during research. 


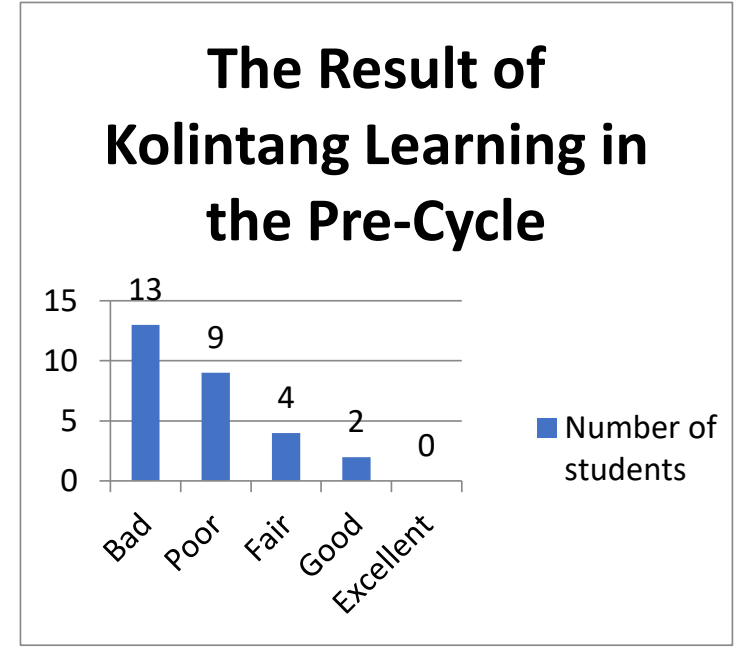

Chart 1 Result of Test on Kolintang learning in the Pre-cycle

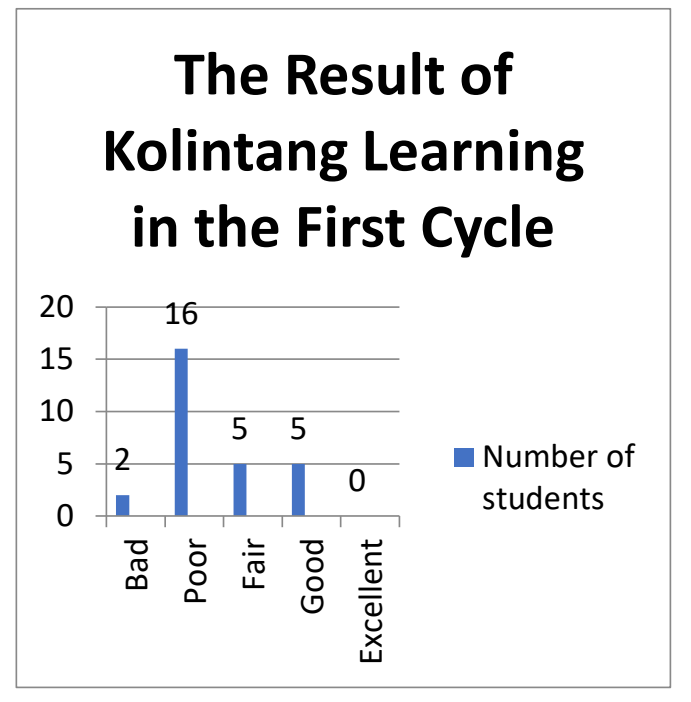

Chart 2 Result of Test on Kolintang learning in the First Cycle

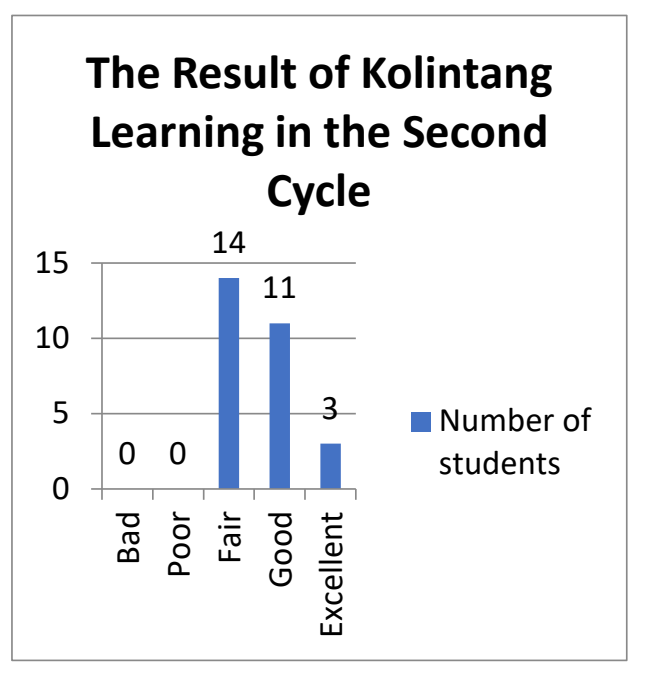

Chart 3 Result of Test on Kolintang learning in the Second Cycle

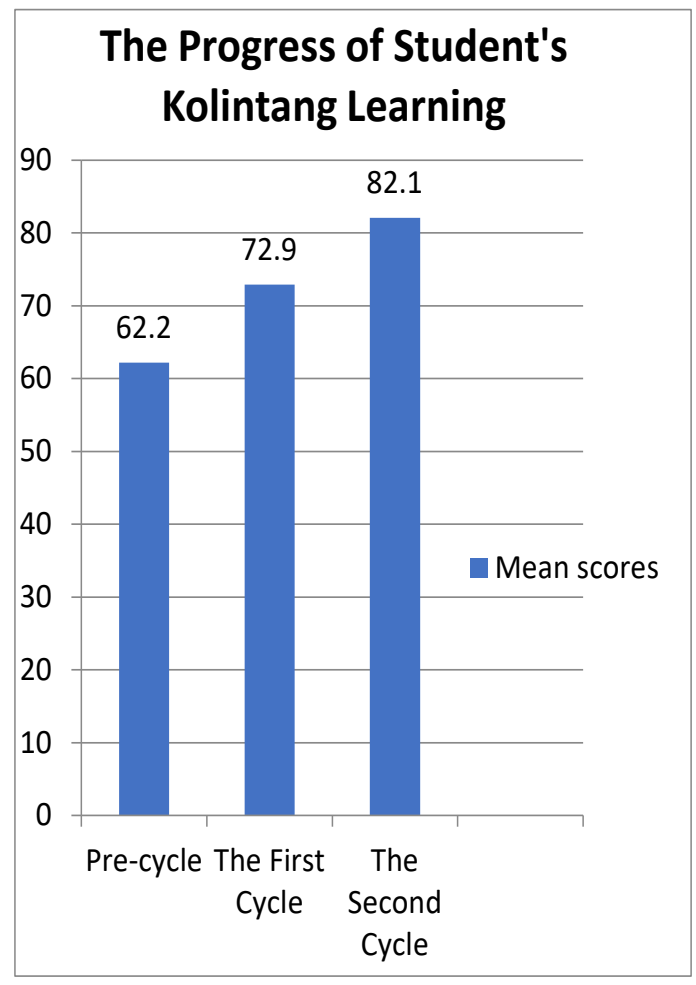

Chart 4 Student's Kolintang Learning Progress 


\section{CONCLUSION}

Based on the results of treatment conducted in the precycle, the first cycle, and the second cycle, there is an increase in terms of student's achievement in learning. The research on Kolintang learning in SMP Bruderan Purworejo in the 2016-2017 academic year is considered successful.

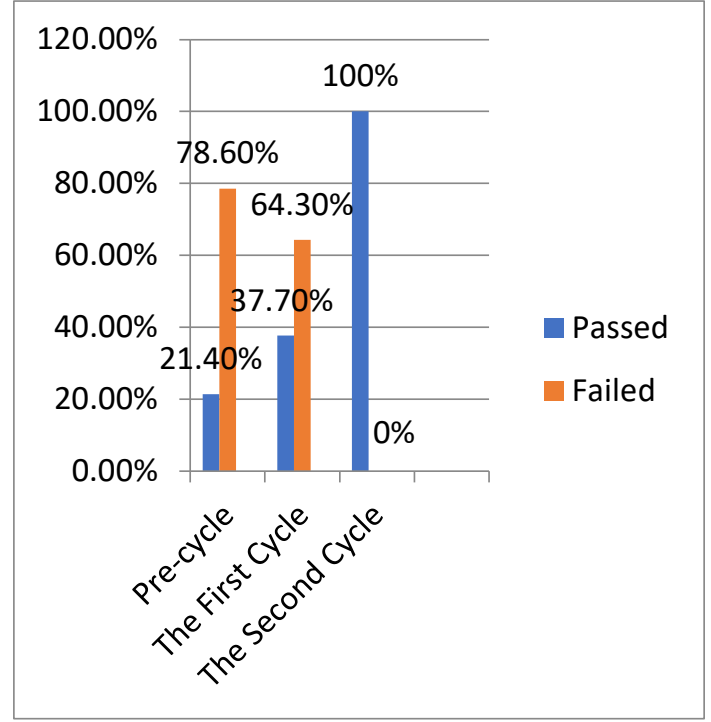

Chart 5 Comparison of Students' Scores in the PreCycle, Cycle I, and Cycle II

With the student's enthusiasm, the researchers can achieve the targeted results although this study needs to go through two cycles in which each cycle includes three meetings and one test.

\section{REFERENCES}

[1] Saputra, Angga Dika. Strategi Pembelajaran Musik Kolintang pada Grup Bapontar Ladies di Sanggar Bapontar Jakarta [Kolintang Music Learning Strategies in the Bapontar Ladies Group at the Bapontar Studio in Jakarta]. Diss. Institut Seni Indonesia Yogyakarta, 2018. p. 3. URL: http://digilib.isi.ac.id/id/eprint/3082

[2] Jasman, Jalil. Panduan Mudah Penelitian Tindakan Kelas [Easy Guide to Classroom Action Research]. Jakarta: Prestasi Pustaka Publisher, 2014. p. 13.

[3] Kunandar. Langkah Mudah Penelitian Tindakan Kelas sebagai Pengembangan Profesi Guru [Easy Steps to Classroom Action Research as Teacher Professional Development]. Jakarta: PT Raja Grafindo Persada, 2008. p. 80.

[4] Riduwan, Akhmad. Metode Riset [Research Method]. Rineka Cipta, 2004. p. 104.

[5] Sugiyono. Memahami Penelitian Kualitatif [Understanding Qualitative Research]. Bandung: Alfabeta, 2014.

[6] Arikunto, Suharsimi. Prosedur Penelitian: suatu pendekatan praktik [Research Procedure: A Practical Approach]. Rineka Cipta, 2008. p. 137. 